\title{
TEOLOGI RASIONAL PADA PESANTREN TRADISIONAL: Telaah Konsep Teologi pada Buku Daras Teologi di Pesantren Musthafawiyah
}

\author{
Salamuddin \\ Fakultas Ilmu Tarbiyah dan Keguruan IAIN Sumatera Utara \\ Jl. Willem Iskandar Pasar V Medan Estate, Medan, 20371 \\ e-mail: salamdin@gmail.com
}

\begin{abstract}
Abstrak: Tulisan ini berupaya mengkaji apakah konsep teologi yang terdapat dalam buku daras teologi di pesantren Musthafawiyah bersifat rasional atau tradisional. Metode yang digunakan adalah dengan menelaah secara mendalam konsepkonsep teologi yang terdapat pada buku-buku tersebut dan menimbangnya dengan tolak ukur ilmu logika (manthiq). Temuan yang dihasilkan menunjukkan bahwa konsep teologi yang terdapat pada buku daras tersebut bersifat rasional. Rasionalitas teologi itu diyakini merupakan salah satu faktor yang menyebabkan dapat diterima oleh masyarakat umumnya, alumni atau santri yang sedang belajar di pesantren ini khususnya, sehingga tetap dapat bertahan hingga saat ini. Rasionalitas itu dapat dilihat pada kajian tentang keberadaan Tuhan, sifat-sifat, dan keadilan-Nya, perbuatan manusia dan definisi iman yang dalam buku-buku daras tersebut didasarkan pada argumentasi 'aqal, bukan naqal, sama dengan apa yang dilakukan oleh Muktazilah.
\end{abstract}

\begin{abstract}
Rational Theology in Traditional Pesantren: An Analysis of Theological Concept of Theology Textbook in Pesantren Musthafawiyah. This essay tries to study whether the theological concepts that are written on theology text books at the Islamic boarding school of Musthafawiyah are rational or traditional. The methode used in this essay is an indept study on the theological concepts found in such textbooks while analyzing them through logic. This study reveals that theological concepts in those textbooks are is rational in character. The rationality of this theological concept is believed to be factor that lead to well reception by the community, graduatesand especially active students of this boarding school and thus it can survive challenges till today. This rationality of the text is evident in such discussion as the existence of God, His attributes and justice, as well as on human actions and the articles of faith, all of which are based on logic rather than dogma like those of the Muktazilite's.
\end{abstract}

Kata Kunci: teologi, rasional, tradisional, modern, buku daras, Musthafawiyah 


\section{Pendahuluan}

Salah satu ciri dari masyarakat modern adalah menjunjung tinggi rasionalitas. Penerimaan dan penolakan manusia modern akan sesuatu, baik berupa konsep dan pemikiran sangat bergantung pada sesuai atau tidaknya dengan akal (rasio). Kesimpulan yang benar bisa saja akan ditolak jika bangunan proposisi dan asas berpikirnya bertentangan dengan prinsip-prinsip logika. Dengan demikian, rasionalisasi sangat dibutuhkan dalam semua aspek jika ingin tetap eksis dan diterima pada era global ini.

Teologi sebagai sesuatu yang mendasar bagi sebuah agama tidak terkecuali harus dibangun sesuai dengan prinsip berpikir yang benar sehingga dapat diterima oleh masyarakat modern dan tidak ditinggalkan karena bertentangan dengan rasio. Berbagai aliran teologi yang berkembang di dunia Islam telah banyak ditinggalkan oleh penganutnya karena tidak sesuai dengan tuntutan modernitas.

Sebagai salah satu pesantren tertua dan berpengaruh di Sumatera Utara, Musthafawiyah telah eksis selama lebih dari satu abad dan telah mewisuda puluhan ribu santri yang tersebar di semua penjuru dengan beragam profesi di Indonesia. Andil dan peran pesantren ini di masyarakat telah diakui, selain karena penyebaran alumninya dan pengaruh mereka di berbagai lini, kekuatannya bertahan hingga saat ini dan tetap diminati oleh stakeholder adalah sisi lain yang mengundang pertanyaan.

Tanpa bermaksud mengabaikan variabel lain, variabel teologi kelihatannya salah satu yang sangat menentukan kekuatan itu, sehingga pertanyaan apakah konsep teologi yang terdapat dalam buku daras pesantren ini bersifat rasional sehingga dapat diterima masyarakat modern dan mampu menciptakan imun dalam menghadapi tantangan kekinian?

\section{Pesantren Musthafawiyah}

Pesantren Musthafawiyah didirikan oleh Syaikh Musthafa Husein pada 12 Desember tahun 1912 di desa Tano Bato. Namun belakangan dipindahkan ke desa Purba Baru setelah peristiwa banjir bandang yang terjadi pada 28 November tahun 1915. Desa Purba Baru saat ini masuk dalam kecamatan Lembah Sorik Marapi dengan ibukota Pasar Maga, kabupaten Mandailing Natal, provinsi Sumatera Utara.

Desa ini diapit oleh dua bukit yang dalam bahasa Mandailing disebut tor, yaitu Tor Roburan di sebelah barat dan Tor Aek Tapus di sebelah timur. Sepanjang desa ini mengalir sungai yang dalam bahasa Mandailing disebut aek, yaitu Aek Singolot yang mengandung zat belerang karena berasal dari gunung Sorik Marapi yang masih aktif, dan bermuara ke sungai Batang Gadis, atau dalam bahasa Mandailing Aek Godang di desa Aek Godang yang bertetangga dengan desa Purba Baru. Sungai lain yang mengalir di desa Purba Baru, tepatnya di sebelah timur adalah Aek Tapus yang daerah alirannya menyusuri Tor Aek Tapus.

Desa Purba Baru berjarak 17 kilometer dari kota Panyabungan sebagai ibu kota 
kabupaten Mandailing Natal, berjarak 90 kilometer dari kota Padang Sidempuan, berjarak 500 kilometer dari kota Medan, ibu kota Sumatera Utara, dan berjarak 247 kilometer dari kota Bukit Tinggi, Sumatera Barat. ${ }^{1}$

Sejak didirikan pada tahun 1912 sampai wafatnya Syaikh Musthafa Husein pada tahun 1955, kepemimpinan pesantren tetap berada di tangannya. Pada periode tersebut Syaikh Musthafa Husein memegang kepemimpinan tunggal (single leader). Ia hanya dibantu oleh seorang sekretaris dan bendahara dalam mengoperasikan pesantren, dan pada akhir jabatannya, ia mewariskan 9 ruang belajar dan 450 orang santri. ${ }^{2}$

Setelah ia wafat, jabatan Mudir (pimpinan) pesantren telah mengalami pergantian sebanyak tiga kali, yaitu H. Abdullah Musthafa (1955-1995), H. Abdul Khalik Nasution (1995-2004), H. Musthafa Bakri (2004-sekarang). Sedangkan jabatan Rấis al-Mu'allimîn (kepemimpinan edukatif) telah mengalami pergantian sebanyak enam kali, yaitu Syaikh Abdul Halim Khatib (1955-1985), Syaikh Syamsuddin Hasibuan (1985-1991), Syekh H. M. Yunus Nasution (1991-1992), Syaikh H. Mukhtar Siregar (1992-2003), Syaikh Umar Lubis (2003-2010), dan H. M. Yakub Lubis (2010-sekarang).

Dengan merujuk pada pendapat Muhammad Bahri Gazali, ${ }^{3}$ pesantren Musthafawiyah masuk kategori pesantren tradisional. Tiga karakteristik pesantren tradisional yang dikemukakannya ada pada pesantren ini, yaitu 1) mempertahankan bentuk asalnya, 2) dari sisi kurikulum pembelajaran merujuk pada kitab-kitab yang ditulis oleh ulama-ulama abad 15 , dan 3) masih mempertahankan sistem halaqah pada proses pembelajaran ekstrakurikuler.

\section{Buku Daras Teologi pada Pesantren Musthafawiyah}

Sesuai dengan jumlah tingkatan kelas yang ada di pesantren Musthafawiyah yang terdiri dari tujuh tingkat, maka buku daras teologi yang digunakan juga berjumlah tujuh buah. Di antara buku daras teologi yang dipelajari di pesantren Musthafawiyah berjudul

${ }^{1}$ Profil Pondok Pesantren Musthafawiyah Purba Baru Kabupaten Mandailing Natal (Purba Baru: 2012), h. 1.

${ }^{2} I b i d$, h. 3.

${ }^{3}$ Muhammad Bahri Gazali membagi pesantren kepada tiga kategori. Pertama, Pesantren Tradisional, yaitu pesantren yang masih mempertahankan bentuk asalnya dengan merujuk pada kitab-kitab yang ditulis oleh ulama-ulama abad ke-15, dan sistem pembelajarannya menerapkan sistem halaqah yang diadakan di masjid atau surau serta kurikulumnya sepenuhnya bergantung kepada kepakaran kiai. Kedua, pesantren modern yang telah meninggalkan sistem pembelajaran tradisional. Pesantren ini telah menggunakan sistem dan kurikulum madrasah atau sekolah. Perbedaannya terletak pada penekanannya pada pendidikan agama dan bahasa Arab. Ketiga, pesantren komprehensif yang mengembangkan sistem pesantren tradisional dan modern, kemudian menambah pendidikan keterampilan dan kemasyarakatan serta berperan aktif di tengah-tengah masyarakat. Muhammad Bahri Gazali, Pendidikan Pesantren Berwawasan Lingkungan: Kasus Pondok Pesantren an-Nuqayah Guluk-Guluk Sumenep Madura (Jakarta: Pedoman Ilmu, 2001), h. 14-15. 
Durûs al-Aqấid al-Diniyah karya 'Abd al-Rahmân bin Siqâf bin Husein al-Siqâf., Jilid I, II untuk kelas I, dan jilid III untuk kelas II.

Sementara di kelas III dipelajari Fath al-Majîd karya Syaikh Muhammad Nawawi ibn Umar al-Jawi al-Syafiî̀ (1813-1897), sering disebut dengan Nawawi Banten. Buku

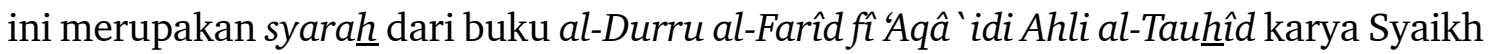
Ahmad ibn al-Sayyid 'Abd al-Rahman al-Nahrawi.

Kemudian di kelas IV diajarkan buku teologi berjudul Tahqqîq al-Maqâm 'alâ Kifâyah al-Awwâm fì mâ Yajibu 'Alaihim min al-'Imi al-Kalâm karya Syaikh Ibrâhîm al-Bajûrî (w. 1277H./1861H.), murid dari Syaikh Muhammad al-Fadali al-Syafiî̀ (w. 1236H./1821M.). ${ }^{4}$ Buku ini merupakan penjelasan (syarah) dari buku Kifâyah al-Awwâm fí Mâ Yajibu Alaihim min 'Ilmi al-Kalâm karya gurunya.

Buku daras teologi yang digunakan di kelas V adalah al-Husûn al-Hamîdiyah li alMuhâfazah 'alâ al-'Aqâ ' id al-Islâmiyah karya al-Sayyid Husein Afandî al-Jasrî at-Tarâblusî (w. 1909 M.). Karya ini ditulis oleh pengarangnya karena permintaan Khalifah Abdul Hamid kekhalifahan Usmani sebagai respon atas perkembangan ilmiah, khususnya dalam bidang filsafat di masanya. Al-Sayyid Husein Afandî al-Jasrî at-Tarâblusî menjelaskan, bahwa materi filsafat yang mengemuka ketika itu dikhawatirkan merusak sendi-sendi teologi umat, apalagi bila dibaca oleh masyarakat awam, maka atas dasar itulah khalifah memintanya menyusun buku ini. ${ }^{5}$ Martin Van Bruinessen menyatakan, bahwa pengarang ini merupakan seorang tokoh modernis dan moderat dan berusaha mengintegrasikan Islam dengan ilmu modern dan filsafat dalam karya-karyanya yang lain. ${ }^{6}$

Sementara buku daras yang digunakan di kelas VI dan VII berjudul Hâsyiyah alDusukî 'alâ Ummi al-Barâhîn karya Syaikh Muhammad al-Dusukî (w. 1230 H./1815M.), dan merupakan komentar atas Syarh Ummi al-Barâhîn karya Abû 'Abd Allâh Muhammad bin Yûsuf al-Sanusi (w. 895H./1490M.).

Tulisan ini tidak akan mengkaji semua buku daras teologi yang terdapat di pesantren Musthafawiyah, tetapi hanya buku daras yang diajarkan di kelas III sampai kelas VII. Buku daras kelas I, II dan III, isinya masih merupakan pengantar dan belum membahas tematema krusial yang menjadi diskursus panjang di kalangan ahli, sehingga kurang relevan dengan judul yang sedang dibahas.

${ }^{4}$ Terdapat dua buah karya Syaikh Ibrâhîm al-Bajûrî yang dijadikan sebagai buku daras di pesantren Musthafawiyah. Pertama, Syarh Kifâyah al-Awwâm dalam bidang teologi, dan kedua al-Bâjurî dalam bidang fikih yang diajarkan di kelas III dan VI. Al-Bâjurî merupakan syarah dari buku Fath al-Qarîb. Sirajuddiin Abbas, Sejarah \& Keagungan Mazhab Syafi'I, Cet. 15 (Jakarta: Pustaka Tarbiyah Baru, 2007), h. 243.

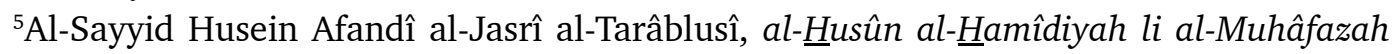
'alâ al-Aqâ 'id al-Islâmiyah (Surabaya: Muhammad bin Ahmad Nabhân wa Awlâduh, t.t.), h. 3-5.

${ }^{6}$ Martin Van Bruinessen, Kitab Kuning Pesantren dan Tarekat, Cet. 3 (Bandung: Mizan, 1999), h. 157.

${ }^{7}$ Tsuroya Kiswati, Al-Juwaini: Peletak Dasar Teologi Rasional dalam Islam (Jakarta: Erlangga, 48 


\section{Term Rasional dan Tradisional dalam Teologi}

Mengkaji teologi pada dasarnya merupakan upaya memahami kerangka berpikir dan proses pengambilan keputusan para ahli dalam merespon diskursus teologi. Potensi yang dimiliki manusia secara natural akan berpengaruh terhadap temuan yang dihasilkannya secara natural pula. Persoalan keyakinan, syariah, dan politik juga merupakan aspek-aspek yang memicu terjadinya perbedaan pendapat, selain perbedaan metode yang digunakan dalam menganalisis persoalan. Perbedaan metode itu pada akhirnya melahirkan corak pemikiran dalam objek yang sedang ditelaah.

Sesuai latar belakang, konteks dan metodenya, mayoritas ahli menjelaskan corak teologi secara beragam. Tsuroya Kiswati, ${ }^{7}$ Masdar F. Mas'udi, ${ }^{8}$ Zainun Kamal, ${ }^{9}$ dan Harun Nasution membagi corak teologi umat Islam kepada dua macam, yaitu rasional dan tradisional. ${ }^{10}$

Menurut Harun Nasution, yang tergolong teologi rasional adalah aliran Muktazilah dengan karakteristik sebagai berikut; 1) penghargaan yang tinggi terhadap akal, 2) manusia memiliki kebebasan dalam kehendak dan perbuatan, 3) kebebasan berpikir hanya terikat pada ajaran-ajaran dasar dalam al-Qur'an dan hadis, yang jumlahnya sangat sedikit, 4) percaya pada adanya sunnah Allah dan kausalitas, 5) mengambil arti metaforis atas teks wahyu, dan 6) dinamis dalam sikap dan berpikir. ${ }^{11}$ Sedangkan yang tergolong teologi tradisional ${ }^{12}$ adalah aliran Asy'ariyah dengan karakteristik sebagai berikut; 1) menempatkan akal pada posisi yang rendah, 2) manusia tidak bebas dalam kehendak dan perbuatan, 3) kebebasan berpikir terikat dengan ayat al-Qur'an dan hadis, 4) tidak percaya pada sunnah Allah dan kausalitas, 5) terikat dengan makna tekstual al-Qur'an dan hadis, dan 6) statis dalam sikap dan berpikir. ${ }^{13}$

Lepas dari teori yang dikemukakan Harun Nasution di atas, jika dirujuk pada asal

2005), h. 12-13.

${ }^{8}$ Masdar F. Mas'udi, Telaah Kritis Atas Teologi Muktazilah (http://www.scribd. com/doc/ 19075949/kajian-Filsafat-Dan-Teologi-Islam), h. 4.

'Zainun Kamal, Kekuatan dan Kelemahan Paham Asy'ari Sebagai Doktrin Akidah dalam http://media.isnet.org/islam/Paramadina/Konteks/ Asyari3.html. h. 1.

${ }^{10}$ Harun Nasution, Islam Rasional (Bandung: Mizan, 1996), h. 115. Lihat juga, Hasan Zaini, Tafsir Tematik Ayat-ayat Kalam Tafsir al-Maragi (Jakarta: Pedoman Ilmu Jaya, 1997), h. 7.

${ }^{11}$ Harun Nasution, Islam Rasional, h. 112-116.

${ }^{12}$ Kata tradisional berasal dari bahasa Inggris tradition yang diterjemahkan ke dalam bahasa Indonesia sebagai tradisi. Dalam Kamus Umum Bahasa Indonesia, kata tradisi diartikan segala sesuatu, seperti adat, kepercayaan, kebiasaan, ajaran dan sebagainya yang turun temurun dari nenek moyang. Lihat John M. Echols dan Hassan Shadily, Kamus Inggris Indonesia (Jakarta: Gramedia, 1979), h. 599, dan W.J. S. Poerwadarminta, Kamus Umum Bahasa Indonesia (Jakarta: Balai Pustaka, 1991), h. 1088.

${ }^{13}$ Harun Nasution, Islam Rasional, h. 116.

${ }^{14}$ John. M. Echols dan Hassan Shadily, Kamus, h. 466. 
katanya, rasional berasal dari bahasa Inggris, rational, yang berarti masuk akal, berakal. ${ }^{14}$ Kata rasional selanjutnya dapat berarti pemikiran, pandangan dan pendapat yang sejalan dengan pendapat akal. Sedangkan akal dapat berarti daya berpikir yang ada dalam diri manusia dan merupakan salah satu daya dari jiwa serta mengandung arti berpikir, memahami dan mengerti. ${ }^{15}$ Kata akal berasal dari bahasa Arab yaitu 'aqala yang berarti mengikat dan menahan. Pada zaman Jahiliyah, orang yang berakal ('âqil) adalah orang-orang yang dapat menahan amarahnya dan mengendalikan hawa nafsunya, sehingga memiliki sikap dan tindakan yang bijaksana dalam menghadapi segala persoalan. ${ }^{16}$ Disiplin ilmu yang membicarakan tentang tolak ukur dan karakteristik sesuatu itu dapat dikatakan masuk akal atau rasional adalah ilmu logika atau mantik.

Menurut ahli logika (mantik), tolak ukur yang dapat digunakan untuk menilai sesuatu itu dapat disebut rasional (masuk akal) adalah jika ia absah (valid) dan benar (s $\underline{h} a \underline{h} \underline{h} \underline{\text { ) }}$. Menentukan validitas bergantung kepada prosedur penyimpulan apakah sesuai dengan patokan berpikir atau tidak. Prosedur penyimpulan tersebut ada dua, yaitu induksi dan deduksi. Induksi adalah cara berpikir untuk menarik kesimpulan yang bersifat umum dari kasus-kasus yang bersifat individual. Seperti 'besi dipanaskan memuai, seng dipanaskan memuai, emas dipanaskan memuai, platina dipanaskan memuai, maka semua logam jika dipanaskan memuai'. Sementara deduksi adalah kegiatan berpikir dari pernyataan yang bersifat umum, menuju kesimpulan yang bersifat khusus. Seperti 'semua logam bila dipanaskan memuai, tembaga adalah logam, maka tembaga bila dipanaskan memuai'. ${ }^{17}$

Sementara tolak ukur yang digunakan untuk menilai sesuatu itu dapat disebut benar (shah $\underline{h} \underline{h}$ ) bergantung kepada proposisi yang digunakan dalam silogisme apakah sesuai dengan fakta atau tidak, seperti proposisi; 'batu lebih berat daripada kapuk' dan 'bumi bergerak mengelilingi matahari'. Kemudian tolak ukur berikutnya adalah adanya persesuaian atau tidak adanya pertentangan dalam dirinya. Suatu pernyataan dapat dikatakan benar manakala ia tidak mengandung pertentangan dari awal hingga akhir. Pernyataan; 'Fatimah adalah seorang bisu yang pandai berdebat, ia adalah seorang jujur yang suka menipu, adalah pernyataan yang tidak sesuai dengan prinsip logika. ${ }^{18}$

Kemudian dalam aktivitas berpikir perlu diperhatikan asas berpikir. Asas adalah pangkal atau asal dari mana sesuatu itu muncul dan dimengerti. Kapasitas asas ini bagi kelurusan berpikir mutlak, dan salah benarnya suatu pemikiran tergantung terlaksana tidaknya asas-asas ini. Asas pemikiran ini dapat dibedakan menjadi tiga: ${ }^{19}$ Pertama, Asas identitas (principium identitatis = qanun zatiyah). Ia adalah dasar dari semua pemikiran dan bahkan

\footnotetext{
${ }^{15}$ Kafrawi Ridwan (Ed.), Ensiklopedi Islam (Jakarta: Ichtiar Baru van Hoeve, 1999), h. 98. ${ }^{16} I$ Ibid, h. 98.

${ }^{17}$ Mundiri, Logika (Jakarta: RajaGrafindo Persada, 1994), h. 13-14.

${ }^{18}$ Ibid., h. 9-10.

${ }^{19}$ Ibid., h. 11-13.
} 
asas pemikiran yang lain. Prinsip ini mengatakan bahwa sesuatu itu adalah dia sendiri bukan lainnya. Jika kita mengakui sesuatu itu Z maka ia adalah Z dan bukan A, B atau C. Kedua, Asas kontradiksi (principium contradictoris = qanun tanaqud). Prinsip ini mengatakan bahwa pengingkaran sesuatu tidak sama dengan pengakuannya. Jika kita mengatakan bahwa sesuatu itu bukan A maka tidak mungkin pada saat itu ia adalah A, sebab relitas ini hanya satu sebagaimana disebut oleh asas identitas. Ketiga, Asas penolakan kemungkinan ketiga (principium exlusi tertii = qanun imtina'). Asas ini menyatakan bahwa antara pengakuan dan pengingkaran kebenarannya terletak pada salah satunya. Suatu proposisi selalu dalam keadaan benar atau salah.

Mengacu pada judul tulisan ini, maka pisau analisis yang akan digunakan untuk melihat rasionalitas teologi yang terdapat pada buku daras teologi di pesantren Musthafawiyah merujuk pada prinsip-prinsip berpikir yang terdapat dalam ilmu logika, bukan berdasar pada pendapat Harun Nasution sebagaimana dijelaskan sebelumnya. Namun, mengingat banyaknya tema perbincangan yang terdapat dalam buku daras tersebut, maka tema yang akan dibahas dibatasi pada diskursus yang menjadi perbincangan para ahli teologi, yaitu seputar akal dan wahyu, sifat Tuhan, kekuasaan dan kehendak Tuhan, perbuatan Tuhan, perbuatan manusia, keadilan Tuhan, dan konsep iman.

\section{Diskursus Tema Pokok Teologi dalam Buku Daras Teologi di Pesantren Musthafawiyah}

\section{Akal dan Wahyu}

Dalam diskursus teologi, akal dan wahyu menempati prioritas utama, karena berkaitan dengan konsepsi tentang Tuhan. Akal, sebagai daya berpikir yang ada dalam diri manusia, berusaha keras untuk sampai kepada zat Tuhan, dan wahyu sebagai pengkabaran dari alam metafisika turun kepada manusia sebagai keterangan-keterangan tentang Tuhan dan kewajiban-kewajiban manusia kepada Tuhan.

Berkenaan dengan ini buku-buku teks teologi di pesantren Musthafawiyah menempatkan posisi akal begitu dominan dan sangat berperan untuk mengetahui dan menetapkan keberadaan Tuhan. Buktinya, berbagai buku daras tersebut selalu mengawali penjelasannya dengan hukum akal. Setelah itu baru dianjurkan dengan diskursus lain terkait dengan teologi. Syaikh al-Dusuki misalnya, menjelaskan dalam kitab Hasyiah al-Dusuki 'ala Ummi

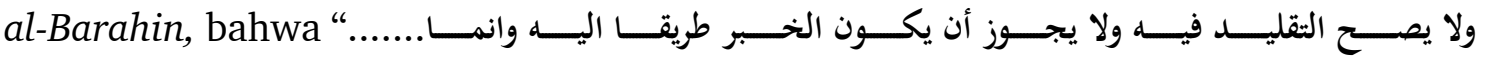

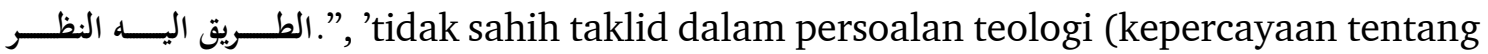
keberadaan Allah), juga tidak sahih kepercayaan teologi dengan berdasar pada al-Qur'an dan Sunnah, yang dapat menghantarkan pada kepercayaan yang sahih hanya al-nazru. ${ }^{20}$

\footnotetext{
${ }^{20}$ Syaikh Muhammad al-Dusûkî, Hâsyiah al-Dusûkî'alâ Ummi al-Barâhîn (Semarang: Karya
} 
Makna al-nazhru di sini adalah pemikiran sistematis, logis dan koheren yang menghantarkan kepada pengetahuan bernilai ilmu karena didukung oleh proposisi yang dirangkai menjadi silogisme yang meyakinkan, seperti ungkapan 'alam adalah baru, dan setiap yang baru pasti ada penciptanya, atau menghantarkan kepada zhan karena hanya didukung oleh proposisi yang bersifat zhanni pada kasus cabang (furu'iyah), seperti ungkapan 'orang ini menenteng senjata di malam hari, setiap penenteng senjata di malam hari adalah pencuri, maka orang ini adalah pencuri'. ${ }^{21}$

Uraian di atas menggambarkan bahwa posisi akal dalam buku daras teologi di pesantren Musthafawiyah sangat dominan, sehingga sahih tidaknya iman seseorang harus didasarkan kepada akal dan tidak cukup dengan hanya mendasarkannya pada al-Qur'an dan Sunnah. Alasannya menurut Syaikh Muhammad al-Dusuki adalah "penetapan akal atas keberadaan Allah merupakan keniscayaan yang pertama sebelum merujuk kepada berita yang datang dari Allah". Menurutnya, hal ini sesuai dengan kaidah ilmu usul fikih yang

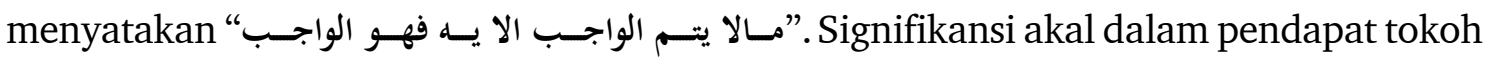
ini dikecualikan pada diskursus sifat sama, basar, kalam, dan mukjizat yang kesahihannya ditentukan oleh al-Qur'an dan Sunnah, sementara diskursus yang lain harus didasarkan kepada akal. ${ }^{22}$

Dengan demikian, peran akal dalam struktur pemahaman yang dikembangkan dalam buku tersebut, demikian juga dalam buku daras teologi yang lain, sangat penting, bahkan menentukan sahih tidaknya kepercayaan teologi penganutnya, dan pada ranah ini wahyu hanya berfungsi sebagai konfirmasi dan penjelas bagi temuan akal.

Akan tetapi terkait diskursus tentang pengetahuan manusia seputar kewajibannya kepada Tuhan diperoleh bukan melalui akal, tetapi melalui al-Qur'an dan Sunnah. Pengecualian yang dikemukakan pada uraian sebelumnya mengindikasikan, bahwa Syaikh Muhammad al-Dusuki berupaya mendudukkan akal dan wahyu secara sejajar. Manakala akal telah sampai kepada konklusi adanya Tuhan, maka konsekuensinya akal juga akan menerima pesan ketuhanan, sehingga tatkala Tuhan menjelaskan lewat ayatnya bahwa Ia Maha Mendengar dan Maha Melihat (وهـــ السـميع العليــم), maka akal akan menerimanya karena selain sebagai konsekuensi dari konklusi penerimaan keberadaan Tuhan, penyifatan ini juga sesuai dengan akal.

Alasan upaya penyelarasan akal dan wahyu kelihatnnya menjadi ikon penting dalam berbagai buku teologi yang diajarkan di pesantren Musthafawiyah, sehingga sejauh ini peneliti belum menemukan ungkapan mereka yang membenturkan konklusi akal dengan pesan wahyu. Al-Sayyid Husein Afandi al-Jasri al-Tarablusi dalam al-Husun al-Hamidiyah li al-Muhafazah 'ala 'Aqa 'idi al-Islamiyah menjelaskan sebagai berikut:23

Toha Putera, t.t.), h. 60 .

${ }^{21}$ Ibid. 


$$
\begin{aligned}
& \text { اعلم أنه كما ورد في الشريعة المحمدية م ـا يفيد وصف الله تعالى بصفات مالية، منها ما قامت }
\end{aligned}
$$

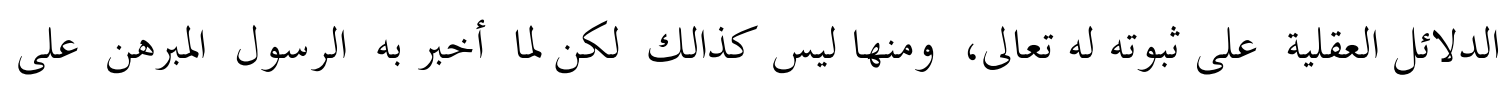

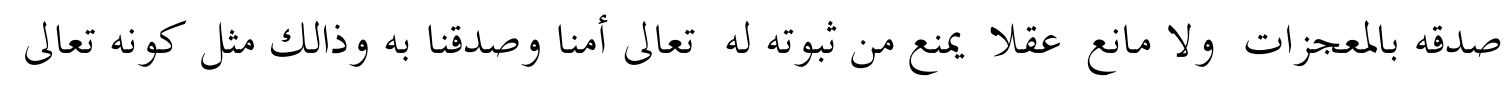

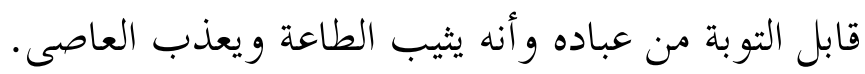

Terkait persoalan kewajiban berterima kasih kepada Tuhan, dan tuntutan berbuat baik dan menjauhi yang buruk dapat dirujuk kepada uraian Syaikh Muhammad al-Dusuki dalam Hasyiah al-Dusuki 'ala Ummi al-Barahin. Sebelum menjelaskan secara detail hukum akal, Syaikh al-Dusuki terlebih dahulu menguraikan defenisi hukum, dan apa yang menjadi

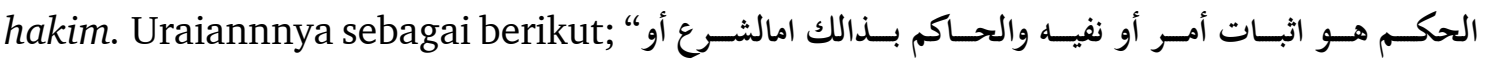

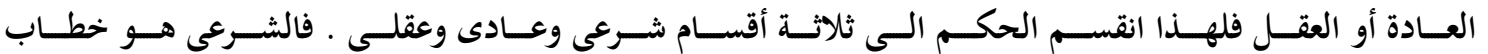
Uraian ini menggambarkan bahwa ia berupaya memposisikan ketiga hakim itu dalam kaitannya dengan diskursus teologi, dan jika dikaitkan dengan kewajiban berterima kasih kepada Tuhan dan tuntutan berbuat baik dan menjauhi yang buruk, maka ini merupakan ranah syara', bukan ranah akal dan adat. Syara' berfungsi menjadi hakim sebagai konsekuensi kesimpulan akal tentang kemampuannya mengetahui adanya Tuhan serta bukti-bukti keberadaanNya. Tuhan sebagai zat yang diyakini lewat argumentsi (hujjah) menurunkan beberapa ketetapan yang harus dan boleh dilakukan manusia dan terangkum dalam hukum

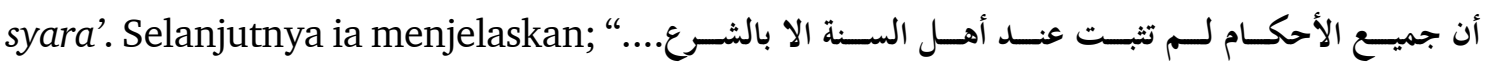

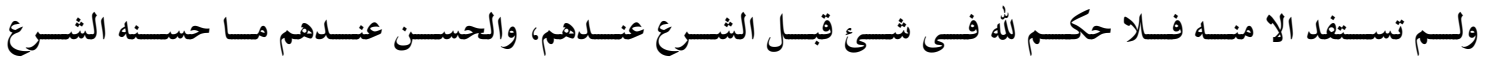
 kan ketetapan syara', tidak ada hukum tentang segala sesuatu menurut mereka sebelum turunnya hukum syara', baik dan buruk merupakan ketetapan syara'.

Dengan demikian, pengetahuan tentang perlunya berterima kasih kepada Tuhan, dan tuntutan berbuat baik dan menjauhi yang buruk bukan muncul dari akal, tetapi dari wahyu sebagai konsekuensi logis penerimaan akal akan keberadaan Tuhan. Kesimpulan ini bertentangan dengan pendapat Muktazilah yang menyatakan bahwa tuntutan itu diketahui lewat akal, sementara wahyu hanya sebagai alat konfirmasi terhadap akal.

\section{Sifat Tuhan}

Persoalan transendensi dalam teologi Islam merupakan permasalahan yang sangat berat ditemukan pemecahannya oleh pemikiran teologi. Di antara yang menjadi persoalan dalam transendensi adalah perbincangan tentang atribut (sifat) Tuhan. Di dalam teologi

${ }^{22} I b i d .$, h. 60. 
Islam terdapat pertentangan yang sangat tajam tentang apakah Tuhan, sebagai Zat Yang Unik, mempunyai sifat ataukah tidak, ${ }^{26}$ yaitu sesuatu yang mempunyai wujud tersendiri.

Terkait dengan diskursus ini, Syaikh Muhammad al-Dusuki menjelaskan, bahwa sifat bukan zat (مـا ليسس ذاتـ), tetapi sesuatu yang ada pada zat (لاماكـان موجسودا فـى الخـارج), dan bukan merupakan tambahan bagi zat (ليسـ زائسدا على الــذات).

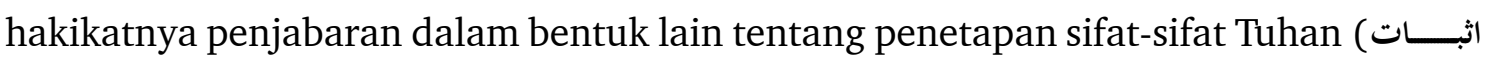
Akan tetapi tujuan yang hendak diperoleh dengan pernyataan tersebut adalah pemurnian kemahasucian Tuhan dan kritik atas pemahaman Muktazilah yang menyamakan pengetahuan, kekuasaan, penglihatan dan sebagainya dengan zat Tuhan. Karena sebagai seorang pemikir teologi, Syaikh Muhammad al-Dusuki mesti menempuh pendekatan tertentu dalam mempertahankan wujud pemikirannya.

Sebagai teolog yang mendasarkan tolak ukur argumentasinya kepada akal, maka untuk memahami terminologi tersebut perlu dirujuk kepada logika (mantiq). Para ahli mantiq (logika) menjelaskan, bahwa tatkala menguraikan tolak ukur bagi sebuah definisi, maka salah satu yang harus diperhatikan adalah kemampuan membedakan antara sifat esensial (zati), aksidental ('arid) dan lazim dari sesuatu. Sifat esensial adalah sifat yang masuk dalam esensi dan hakikat sesuatu, tidak mungkin sesuatu itu dipahami tanpa menyertakan sifat ini. Contoh sifat esensial adalah makna warna yang dipahami dari kata hitam, dan makna benda dari kata pohon. Sifat aksidental adalah sifat yang harus menyertai benda tetapi bisa hilang cepat atau lambat. Sementara sifat lazim adalah sifat yang menyertai benda, tetapi pemahaman hakikat benda itu tidak tergantung padanya, seperti bayangan yang menyertai postur manusia ketika matahari terbit. Memahami hakikat manusia dapat dilakukan tanpa menggunakan kata bayangan sedikit pun. ${ }^{28}$

Dengan demikian, kelihatannya pemahaman sifat yang dikemukakan oleh Syaikh Muhammad al-Dusuki itu merujuk kepada sifat esensial (zati) ini, bukan sifat aksidental ('arid), dan bukan sifat lazim. Karena sifat yang ia maksud adalah sifat yang masuk dalam esensi dan hakikat sesuatu sehingga dengannya keberdaan zat dapat dipahami.

Syaikh Muhammad al-Dusuki membagi sifat kepada empat:

Pertama, nafsiyah yang bermakna "hal yang wajib bagi zat selama zat ada tanpa disebabkan oleh suatu sebab". ${ }^{29}$ Esensi sifat wujud itu sendiri tiada, yang ada adalah zat

${ }^{23}$ Al-Tarâblusî, Al-Husûn, h. 45.

${ }^{24}$ Al-Dusûkî, Hâsyiah, h. 32-33.

${ }^{25}$ Ibid., h. 52.

${ }^{26}$ Term al-shifah berasal dari kata kerja washafa. Dalam bentuk kata kerja al-Qur'an menyebutkannya sebanyak tiga belas kali. Sedangkan dalam bentuk kata dasar dari al-sifah, al-Qur'an tidak pernah menggunakannya. Akan tetapi, yang digunakan al-Qur'an adalah kata-kata dalam bentuk wasf. Term al-shifah dengan menggunakan kata kerja lebih mengacu kepada perbincangan tentang ketuhanan, dan yang mengucapkannya adalah orang-orang yang tidak beriman. Al-Râgib alIsfahânî, Mufradât fí Garîb al-Qur'ân (Beirut: Dâr al-Ma'rifah, t.t.), h. 525. 
Allah. Pendapat ini berbeda dengan pendapat al-Asy`ari, pendiri aliran Asy'ariyah yang menyatakan bahwa wujud adalah zat itu sendiri (الوجسود عيسن الـذات).

Syaikh Ibrâhîm al-Baijurî, sependapat dengan Syaikh Muhammad ad-Dusuki. Menurutnya wujud bukan zat, karena sifat wujud diketahui keberadaannya, sementara zatNya tidak diketahui hakikatnya. ${ }^{30}$ Argumentasi ini ditopang oleh penjelasan Syaikh Muhammad Nawâwî ibn 'Umar al-Jâwî, pengarang buku Fath̆u al-Majîd yang menyatakan,

Wujud tidak ada relitasnya, tapi hanya ada dalam logika. sifat wujud diketahui keberadaannya, sementara zat-Nya tidak diketahui hakikatnya. Maka zat bukan sifat wujudnya, jika sifat wujud merupakan zat-Nya, maka ungkapan 'benda itu ada' akan sama maknanya dengan ungkapan 'benda itu adalah benda', tetapi kenyataannya tidak sama. Dengan demikian wujud berbeda dengan zat. ${ }^{31}$

Kedua salbiyah yang berarti menolak atau menjauhkan segala sesuatu yang tidak layak bagi Allah, tetapi eksistensinya tidak ada. ${ }^{32}$ Termasuk sifat salbiyah adalah qidam, baqa', mukhalifatuhu li al-hawadis, qiyâmuhu bi nafsihi, dan wah̆daniyah.

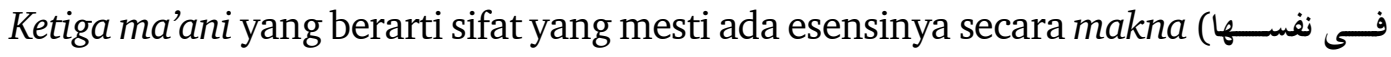

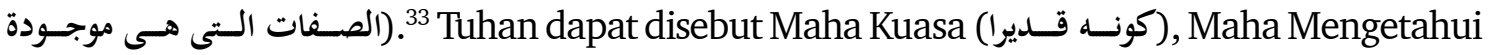

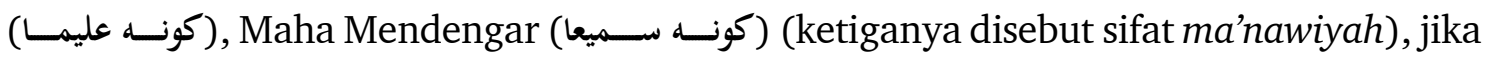
memiliki sifat Qudrat, 'ilmu dan Sama' sebagai sifat Ma'ani. Ma'nawiyah meniscayakan (iltizam) adanya ma'ani. Pengakuan akan Tuhan Maha Melihat (كونسـه بصــيرا), meniscayakan Ia memiliki sifat melihat (بصـر). Proposisi seperti ini dalam terminologi ilmu mantiq disebut qadiyah syartiyah muttasilah luzumiyah (proposisi hipotetik yang mempunyai hubungan keharusan). ${ }^{34}$ Contohnya adalah 'bila sesuatu itu hidup maka ia membutuhkan air' atau 'bila matahari terbit maka waktu salat subuh sudah habis. Termasuk sifat ma'ani adalah qudrat, iradat, ilmu, hayat, sama' basar, dan kalam.

Keempat ma'nawiyah yang berarti esensinya tidak ada, keberadaannya disebabkan oleh suatu sebab (ma'ani), ia menjadi sifat bagi zat selama sebab ('illat) nya tetap ada. ${ }^{35}$ Allah Maha Kuasa, berkehendak, Maha Mengetahui, Hidup, Maha Mendengar, Maha Melihat,

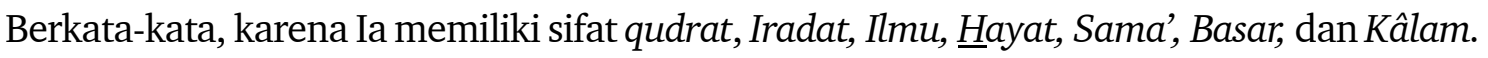

Kendati Tuhan memiliki sifat, tetapi antropomorfisme dalam arti Tuhan mempunyai sifat-sifat jasmani sebagaimana digambarkan teks-teks al-Qur'an tidak diterima dalam

${ }^{27}$ Al-Dusûkî, Hâsyiah, h. 93-94.

${ }^{28}$ Dedi Supriyadi, Pengantar Filsafat Islam (Lanjutan), (Bandung: Pustaka Setia, 2010), h. 126.

${ }^{29}$ Al-Dusûkî, Hâsyiah, h. 93-94.

${ }^{30}$ Syaikh Ibrâhîm al-Baijûri, Tahqîq al-Maqâm 'alâ Kifâyah al-Awwâm fî mâ Yajibu 'Alaihim min al-'Imi al-Kalâm (Indonesia: Dâr Ihyâ' al-'Arabiyah, t.t.) h. 26.

${ }^{31}$ Syaikh Muhammad Nawâwî ibn 'Umar al-Jâwî, Fath al-Majîd Syarh al-Durrî al-Farîd fî 'Aqâ' 'id Ahli al-Tauhîd (Semarang: Toha Putera, t.t.), h. 5. 
penjelasan buku daras yang diajarkan di pesantren Musthafawiyah. Syaikh Muhammad al-Dusuki menjelaskan bahwa "Antropomorfisme bertentangan dengan sifat mukhalafatuhu li al-hawadis. Sifat ini mengharuskan tidak ada yang serupa dengan Allah baik zat, sifat, maupun perbuatan". ${ }^{36}$ Jika terdapat ayat yang makna zahirnya mensifati Tuhan dengan yang baru, maka harus dilakukan takwil demi memelihara kesucian Allah. Sayyid Husein Afandi menyatakan, "Tuhan sebagaimana dinyatakan dalam al-Qur'an memang memiliki muka, tangan, dan sebagaimanya, tetapi makna hakikatnya harus diserahkan kepada Allah dengan tetap menghindari sikap menyamakan Tuhan dengan baharu (antropomorfisme), atau mentakwilkan ayat-ayat itu dengan makna yang sesuai dengan akal. ${ }^{37}$

Penjelasan di atas kembali menegaskan pentingnya tolak ukur logis dalam struktur teologi yang disusun pengarangnya. Manakala ungkapan ayat bertentangan dengan prinsipprinsip akal, maka ta'wil adalah solusinya demi memelihara kesucian Allah. Takwil di sini disyaratkan sesuai dengan dengan akal. Maka muka ditakwilkan menjadi zat, dan tangan ditakwilkan dengan kekuasaan.

Selain itu, ada suatu persoalan yang terkait dengan persoalan tajsîm, yaitu persoalan kalam Allah. Kalam Allah merupakan bagian perbincangan teologi terkait bagaimana manusia dapat berhubungan langsung dengan Tuhan. Sentral bahasannya terletak pada pertanyaan, apakah kalam Allah itu diciptakan atau tidak? Jika diciptakan, maka kalam itu mestilah baru seperti makhluk lain. Seandainya kalam itu tidak diciptakan, maka dia mesti qâdim.

Terkait diskursus ini, buku daras pesantren Musthafawiyah menjelaskan, bahwa kalam Allah yang berada di balik susunan huruf dan kata adalah kalam Allah yang sebenarnya dan bersifat qâdim. Adapun al-Qur'an yang terdiri dari huruf dan kata adalah diciptakan (makhluk). Tegasnya, sumber kalam yang berasal dari Tuhan adalah qâdim karena itu terdapat pada zat Tuhan. ${ }^{38}$

Selain perbincangan kalam, persoalan melihat Allah (ru'yah Allah) juga menjadi diskursus hangat di kalangan teolog. Syaikh Muhammad Nawawi ibni 'Umar al-Jâwî menyatakan, bahwa berdasarkan konsep kemutlakan Tuhan dan kekuasaanNya, dan karena Tuhan ada, setiap yang ada pasti dapat dilihat baik di dunia maupun di akhirat dengan mata kepala. Melihat Tuhan termasuk persoalan yang ja iz bagi Allah. Argumen yang ia kemukakan mengacu kepada firman Allah " 39."فـان اسـتقر مكانسه فسـوف تـرانى. Dalam ayat itu Allah mengaitkan kemungkinan melihatnya dengan tetapnya gunung di tempatnya. Jika gunung yang memiliki kekuatan yang lebih besar dari Musa tidak dapat bertahan di tempatnya, maka Musa juga tidak dapat melihatnya di dunia, tetapi ia akan (سوف) melihat

\footnotetext{
${ }^{32}$ Al-Dusûkî, Hâsyiah, h. 76.

${ }^{33} I b i d .$, h. 97.

${ }^{34}$ A. Basiq Djalil, Logika (Ilmu Mantiq) (Jakarta: Kencana Prenada Media Group, 2010),

${ }^{35}$ Ibid.
} h. 40 . 
Tuhan di akhirat. Permintaan Musa untuk melihat Tuhan ini menunjukkan bahwa ru'yah merupakan sesuatu yang ja iz, sebab seorang Nabi tidak boleh bersifat bodoh (tidak tahu) terhadap persoalan yang wajib, mustahil, atau ja'iz bagi Allah. Selain itu, jika melihat

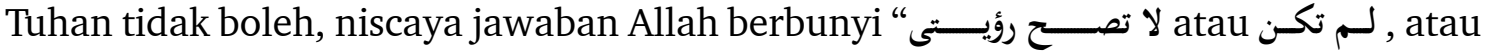

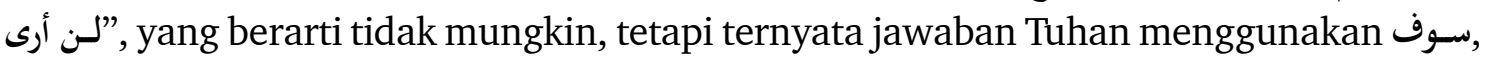
yang berarti kemungkinan melihat Tuhan baik di dunia maupun di akhirat. ${ }^{40}$ Kemudian ayat ini dikuatkan oleh ayat “وجــوه يومئسـ ناضــرة السى ربهــا ناضـرة".

\section{Kekuasaan dan Kehendak Tuhan}

Konklusi logis akal tentang Tuhan sebagai pencipta dan pemilik alam semesta serta memiliki sifat, berimplikasi pada pemikiran bahwa Tuhan memiliki kekuasaan (qudrat) dan kehendak (iradat) yang bersifat mutlak. Kekuasaan dan kehendak mutlakNya diurai dengan skema pemikiran yang begitu detail, sehingga dapat diposisikan dengan benar, tanpa mencederai keesaan Tuhan dalam berbuat dan berkehendak. Syaikh al-Dusuki menjelaskan sebagai berikut;

Efektivitas kekuasaan dan kehendaknya hanya berlaku bagi sesuatu yang bersifat mungkin, tidak berlaku pada yang wajib dan mustahil. Peran kekuasaan Tuhan berada pada susuatu yang bersifat mungkin, seperti mengadakan atau meniadakan sesuatu, sementara kehendak (irâdat) berfungsi menentukan salah satu kemungkinan, apakah mengadakan atau meniadakannya. Kehendak dan kekuasaan Tuhan selalu sejalan dan tidak pernah bertentangan. Maka dalam kasus Abu Jahal, imanannya adalah sesuatu yang diperintahkan Allah, tetapi ilmuNya mengetahui kekafiran Abu Jahal, sehingga efektifitas iradatnya berlaku pada kekafirannya, bukan pada keimanannya. Posisi kehendak (irâdat) dalam hal ini adalah, pada saat Allah mengetahui kekafiran Abu Jahal, maka kehendaknya (irâdat) juga tidak menghendaki keimanannya. Karena iradatnya hanya terjadi pada sesuatu yang mungkin terjadi. Dalam kasus ini, yang mungkin terjadi adalah kekafiran Abu Jahal, bukan keimannya, maka irâdat-Nya juga tidak menghendaki keimanannya. ${ }^{41}$

Akan tetapi menurut Syaikh Muhammad Nawâwî ibni 'Umar Nawâwî al-Jâwî, istilah efektivitas qudrat di sini harus dipahami sebagai sebab, karena yang berbuat sesugguhnya hanya lah Allah, bukan qudratnya. Maka barang siapa yang meyakini bahwa qudrat Allah efektif, atau perbuatan merupakan hasil kerjasama antara sifat qudrat dan zat Allah, maka keyakinannya itu akan membawa kepada kekafiran. ${ }^{42}$

Karena Tuhan memiliki kekuasaan mutlak, maka Tuhan tidak memiliki kewajibankewajiban terhadap manusia sebagaimana pendapat Muktazilah. Tuhan tidak wajib secara

${ }^{36}$ Al-Dusûkî, Hâsyiah, h. 82-83.

${ }^{37}$ Al-Tarâblusî, Al-Husûn, h. 37-38. 
akal memasukkan orang yang taat ke dalam surga, atau memasukkan orang yang maksiat ke dalam neraka. Keesaan Tuhan dalam perbuatan meniscayaan secara logika kebebasan Tuhan untuk berbuat sesuai kehendak-Nya. ${ }^{43}$

\section{Perbuatan Tuhan}

Tema perbuatan Tuhan dalam buku Fath̆u al-Majî̀ masuk dalam kajian tentang sifat wah̆daniyah. Syaikh Muhammad Nawawi ibni 'Umar Nawâwî al-Jâwî menjelaskan bahwa Allah itu Esa baik dari sisi zat, sifat dan perbuatan. Esa dalam aspek perbuatan bermakna bahwa tidak ada perbuatan seperti perbuatan Allah dan tidak ada makhluk yang memiliki perbuatan, baik yang bersifat usaha (ikhtiari) maupun yang bersifat terpaksa (idtirari). Semua perbuatan dan kejadian merupakan perbuatan Allah. Kam Muttasil yang berarti ada perbuatan seperti perbuatan Allah dan Kam Munfasil yang berarti makhluk memiliki perbuatan, bertentangan dengan keesaan Allah ${ }^{44}$

Penjelasan di atas didukung oleh ayat yang berbunyi “"اناكـل شـئ خلقنــاه بقـــ", menurut

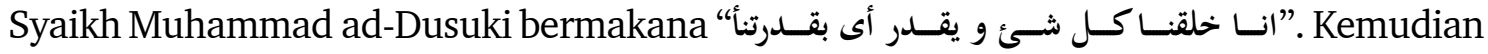

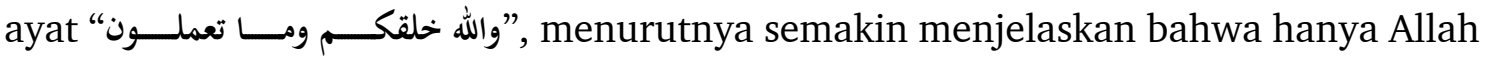
yang memiliki perbuatan. "م" dalam ayat tersebut bisa dipahami sebagai mausulah atau

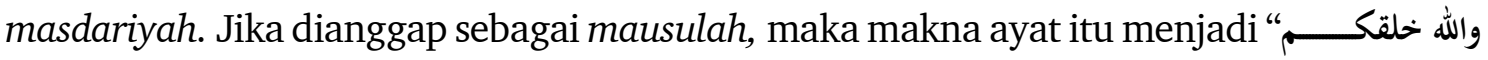

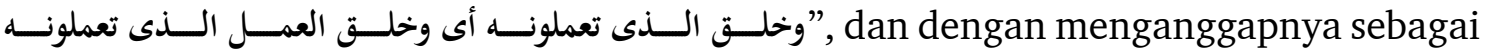

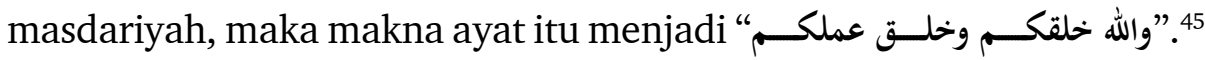

Karena semua perbuatan adalah perbuatan Tuhan, maka di sisi Tuhan, iman, kafir, taat dan maksiat sama saja ditilik dari hukum akal. Tuhan boleh saja menjadikan iman dan taat sebagai tanda masuk neraka, atau kafir dan maksiat sebagai tanda masuk surga. Ini bukan mustahil menurut akal, tetapi sesuatu yang boleh ( $j a i z$ ), sehingga ia boleh saja memberi pahala bagi yang maksiat, atau memberi dosa bagi yang taat. ${ }^{46}$ Memberi pahala kepada yang taat bukan karena kewajibannya tetapi karena karunianya, dan memberi dosa kepada yang maksiat karena keadilannya. Tetapi, sebagai ketetapan Tuhan dalam syara' maka janji itu akan dilaksanakanNya atas dasar mustahilnya Tuhan melanggar janji.

Kebebasan Tuhan dalam berbuat bukan merupakan kezaliman, karena zalim menurut Syaikh Muhammad al-Dusuki adalah berbuat sesuatu pada milik orang lain di luar izinnya. Sementara Tuhan adalah pemilik segala sesuatu dan tidak ada hukum yang mengaturnya. Ia bebas berbuat sesuai dengan kehendaknya. Bertolak dari pemahaman ini maka pengiriman Rasul dan berbuat baik dan terbaik (al-salâh wa al-aslâh) merupakan rahmat Allah bukan

\footnotetext{
${ }^{38}$ Al-Dusûkî, Hâsyiah, h. 114-115.

${ }^{39}$ Ibid.

${ }^{40}$ Al-Jâwî, Fath, h. 39.

${ }^{41}$ Ibid., h. 102.

${ }^{42}$ Ibid, h. 23.
} 
merupakan kewajiban bagi Allah. ${ }^{47}$ Pengiriman para Rasul hanya merupakan kemurahan dan keutamaan Tuhan. Tuhan mempunyai sifat kasih sayang kepada hamba-Nya, Ia tidak menginginkan hamba-Nya terjerumus ke dalam kesesatan akibat tidak adanya petunjuk yang dibawa Rasul. Karenanya, Ia mengirim para Rasul kepada manusia untuk membimbing dan menunjuki mereka. Namun pengiriman Rasul bukan merupakan kewajiban Tuhan sebagaimana dipahami oleh Muktazilah, tetapi merupakan rahman dan rahim Allah. ${ }^{48}$

\section{Perbuatan Manusia}

Syaikh Nawâwî ibni 'Umar al-Jâwî menghadirkan teori kasab (usaha) untuk menjelaskan perbuatan manusia. Melalui kasab Allah memberi pahala kepada manusia atas perbuatan baiknya, dan memberi dosa kepada manusia atas perbuatan buruknya. Pemberian pahala merupakan karunia dari Tuhan (fadlun) dan pemberian dosa merupakan keadilanNya ('adlun). Teori Kasab diistilahkan dengan amrun baina amraini, yang berarti manusia terpaksa (majbur) secara batin dan memiliki pilihan (ikhtiar) secara zahir. Ikhtiar di sini bermakna kasab. Kasab tidak efektif, Ia hanya bermakna kecenderungan (mail) yang dimiliki manusia tatkala akan berbuat sesuatu. Interaksi dengan berbagai objek melahirkan kecenderungan dalam diri manusia untuk melakukan perbuatan. Tetapi perbuatan tidak akan terlaksana tanpa adanya kecenderungan dan kekuatan (qudrah) yang berasal dari Allah. Lewat kasab yang bermakna kecenderungan, perbuatan diasosiasikan kepada manusia secara hukum adat. ${ }^{49}$

Menurutnya, Pendapat ini berbeda dari pendapat yang dikemukakan oleh Muktazilah dan para filosof yang menyatakan bahwa manusia menciptakan perbuatannya lewat kemampuan yang diciptakan oleh Allah, juga berbeda dengan Jabariyah yang berpendapat bahwa manusia terpaksa (majbur) zahir dan batin dalam perbuatannya. Bahkan kelihatannya, pendapat ini juga berbeda dengan pendapaat al-Asy'ari yang menyatakan, bahwa qudrat Tuhan dan kemampuan manusia yang tidak efektif secara bersama melakukan perbuatan..$^{50}$

\section{Keadilan Tuhan}

Syaikh Ibrâhîm al-Bajurî meninjau keadilan Tuhan dari sudut kekuasaan dan kehendak mutlak Tuhan. Tuhan sebagai pemilik yang berkuasa mutlak, dapat berbuat apa saja yang dikehendaki terhadap makhluk-Nya. Pemberian pahala kepada yang taat bukan karena kewajiban tetapi karena karuniaNya, dan pemberian dosa bagi yang maksiat adalah karena

\footnotetext{
${ }^{43}$ Al-Dusûkî, Hâsyiah, h. 47.

${ }^{44}$ Al-Jâwî, Fath̆, h. 42.

${ }^{45}$ Al-Dusûkî, Hâsyiah, h. 92.
} 
keadilanNya. Konsep (as-salah wa al-aslah) sebagaimana dipahami Muktazilah, tidak dapat diterima oleh aliran Ahlu al-Sunnah. ${ }^{51}$

Syaikh Ibrâhîm al-Bajurî menjelaskan bahwa iman secara etimologi bermakna pengakuan secara mutlak (mutlâq al-tasdîq). Menurut terminologi, iman berarti pengakuan (tasdiq) dari jiwa akan segala yang dibawa oleh Nabi Muhammad SAW.52 Sementara menurut al-Sayyid Husein Afandi al-Jasri al-Tarablusi, iman adalah pengetahuan dan keyakinan yang kokoh dari seseorang tentang sifat-sifat wajîb, mustahil, dan ja'iz bagi Allah. ${ }^{53}$

Kemudian Syaikh Muhammad al-Dusuki berpendapat, bahwa iman adalah keyakinan yang kokoh yang muncul dari dalil atau argumentasi yang kuat bahwa Muhammad adalah Rasululah dan apa yang disampaikannya adalah benar. Ungkapannya 'yang muncul dari dalil' mengindikasikan bahwa iman harus didasarkan pada pengetahuan (ma'rifah). Iman yang didasarkan pada taqlid padahal ia memiliki kemampuan analisis, tidak cukup bahkan masih dihukum kafir menurut ulama. ${ }^{54}$

Ketiga definisi di atas menekankan 'pengakuan' sebagai syarat bagi iman. Pengetahun tanpa pengakuan tidak dapat disebut sebagai mukmin, demikian juga pengakuan yang tidak didasarkan kepada pengetahuan menurut definisi kedua dan ketiga.

Kelihatannya definisi ini terkait dengan pendapat aliran Asy'ariyah yang menyatakan bahwa pelaku dosa besar atau fasik masih tetap sebagai mukmin. Bukti bahwa mereka tetap sebagai mukmin menurut al-Juwayni adalah, bahwa ayat-ayat yang berkaitan dengan hukum syariat dikaitkan dengan kata mukmin. Ungkapan yâ ayyuhallazîna âmanû dalam beberapa ayat al-Qur'an ditujukan kepada semua orang mukmin, baik yang berdosa besar, maupun yang tidak melakukan dosa besar. ${ }^{55}$

\section{Penutup}

Berdasarkan pada berbagai data dan fakta yang dikemukakan di atas, dapat disimpulkan, bahwa konsep teologi yang terdapat pada buku daras pesantren Musthafawiyah bersifat rasional. Upaya takwîl terhadap berbagai konsep yang dianggap irasional oleh para pengarang buku itu, menunjukkan betapa mereka sangat konsern pada pentingnya rasionalisasi dalam memahami segala sesuatu yang menyangkut tentang teologi. Rasionalisasi yang dimaksudkan di sini bukan mengakali, tetapi menjadikannya dapat diterima akal karena sesuai dengan hukum logika yang mensyaratkan pada konsistensi dan validitas proposisi yang digunakan, sehingga kesimpulan yang dihasilkan dapat disebut sahih dan rasional.

\footnotetext{
${ }^{46}$ Ibid., h. 47.

${ }^{47}$ Al-Jâwî, Fath, h. 38.

${ }^{48}$ Ibid., h. 5 .

${ }^{49}$ Ibid., h. 17.

${ }^{50}$ Ibid.
} 
Dari sisi kualitas, terkait dengan kajian tentang keberadaan Tuhan, buku-buku daras tersebut menggunakan argumentasi akal, bukan naqal, sama dengan apa yang digunakan oleh Muktazilah. Perbedaannya hanya terletak pada tiga persoalan; apakah manusia dapat mengetahui kewajibannya kepada Tuhan, kewajiban berterima kasih kepada Tuhan, dan tuntutan berbuat baik dan menjauhi yang buruk. Rasionalitas pemikiran yang dikembangkan dalam buku-buku tersebut, juga terefleksi dalam diskursus yang lain, baik dalam mengurai sifat Tuhan, perbuatan Tuhan, perbuatan manusia, keadilan Tuhan, dan defenisi iman.

Rasionalitas teologi yang terdapat dalam buku daras pesantren Musthafawiyah diyakini merupakan salah satu faktor yang menyebabkan ia dapat diterima oleh masyarakat umumnya, alumni dan santri yang sedang belajar di pesantren ini khususnya, sehingga ia tetap bertahan hingga saat ini (era modern).

\section{Pustaka Acuan}

Abbas, Sirajuddiin. Sejarah \& Keagungan Mazhab Syafiì. Jakarta: Pustaka Tarbiyah Baru, 2007.

Al-Baijûrî, Ibrâhîm. Tahqî̀q al-Maqâm 'alâ Kifâyah al-Awwâm fî mâ Yajibu 'Alaihim min al'Imi al-Kalâm. Indonesia: Dâr Ihyâ' al-'Arabiyah, t.t.

Bruinessen, Martin Van. Kitab Kuning Pesantren dan Tarekat. Bandung: Mizan, 1999.

Djalil, A. Basiq. Logika (Ilmu Mantiq). Jakarta: Kencana Prenada Media Group, 2010.

Al-Dusûkî, Muhammad. Hâsyiah al-Dusûkî'alâ Ummi al-Barâhîn. Semarang: Karya Toha Putera, t.t.

Echols, John M. dan Shadily, Hassan. Kamus Inggris Indonesia. t.tp: t.p., 1979.

Gazali, Muhammad Bahri. Pendidikan Pesantren Berwawasan Lingkungan Kasus Pondok Pesantren An-Nuqayah Guluk-Guluk Sumenep Madura. Jakarta: Pedoman Ilmu, 2001.

Al-Isfahânî, Ar-Râgib. Mufradât fí Garîb al-Qur'ân. Beirut: Dâr al-Ma'rifah, t.t.

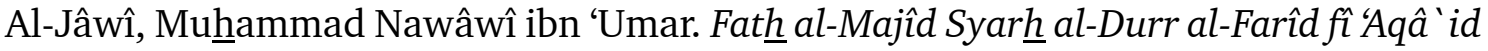
Ahli al-Tauhî̀d. Semarang: Toha Putera, t.t.

Kamal, Zainul. Kekuatan, Kekuatan dan Kelemahan Paham Asy'ari Sebagai Doktrin Akidah. dalam http://media.isnet.org/islam/Paramadina/Konteks/ Asyari3.html.

Kiswati, Tsuroya. Al-Juwaini: Peletak Dasar Teologi Rasional dalam Islam. Jakarta: Erlangga, 2005.

Mas'udi, Masdar F. Telaah Kritis Atas Teologi Muktazilah. dalam http://www.scribd. com/ doc/19075949/kajian-Filsafat-Dan-Teologi-Islam.

Mundiri. Logika. Jakarta: RajaGrafindo Persada, 1994.

Nasution, Harun. Islam Rasional. Bandung: Mizan, 1996. 
Poerwadarminta, W.J. S. Kamus Umum Bahasa Indonesia. Jakarta: Balai Pustaka, 1991.

Profil Pondok Pesantren Musthafawiyah Purba Baru Kabupaten Mandailing Natal Purba Baru: 2012.

Ridwan (ed.), Kafrawi. Ensiklopedi Islam. Jakarta: Ichtiar Baru van Hoeve, 1999.

Supriyadi, Dedi. Pengantar Filsafat Islam. Bandung: Pustaka Setia, 2010.

Al-Tarâblusî, Al-Sayyid Husein Afandî al-Jasrî. Al-Husûnu al-Hamîdiyah li al-Muhâfazah 'ala al-Aqqâ ’id al-Islâmiyah. Surabaya: Muhammad bin Ahmad Nabhân wa Awlâduh, t.t.

Zaini, Hasan. Tafsir Tematik Ayat-ayat Kalam Tafsir al-Maragi. Jakarta: Pedoman Ilmu Jaya, 1997. 